\title{
Research on Assessment of Emergency-response Capability in China's Port Industry
}

\author{
Wang Yukun ${ }^{1,2, a}$, Meng Guodong ${ }^{1,2, b}$, Li Wangyang ${ }^{* 3, c}$, Huang Yali ${ }^{3, d}$ \\ ${ }^{1}$ Tianjin Research Institute for Water Transportation Engineering, M.O.T.,Tianjin, China \\ 2 Tianjin Dong Fang Tai Rui Technology Co., Ltd, Tianjin, China \\ ${ }^{3}$ Offshore Oil Engineering Co., Ltd, Tianjin, China
}

\begin{abstract}
In China's port industry, there is currently a lack of sound, systematic guidance and standards for the assessment of emergency-response capability. Taking the current emergency-management situation in China's port industry as a starting point, this study analyzed current problems in emergency-response capability and examined advanced domestic and foreign practices in emergency management. The elements of emergency-response capability assessment were then established based on the following four aspects: organizational system, legal basis, operation mechanism, and guarantee system. An emergency-response capability assessment method was then constructed using the Delphi method and applied in practice. This method can help guide port businesses in performing their emergency-management duties; improve their prevention, early warning, and emergency-management abilities; and play a guiding role in building emergency-response capability with regard to accident prevention and rescue operations.
\end{abstract}

\section{Introduction}

Port production is characterized by many types of work that can involve numerous hazards. Port work is intermittent and complex, which can also give rise to many potential safety risks. Incidents such as casualties, property loss, and environmental damage are common in port production; examples include the Tianjin Port 8/12 accident and the Dalian Port 7/16 accident. These accidents not only caused many casualties and considerable property loss but also had a negative impact on the surrounding areas.

Therefore, it is important for port businesses to focus on accident prevention. However, they also need to pay attention to timely post-accident emergency management to contain accidents and reduce their scope and severity as much as possible. In this regard, port businesses need to strengthen their emergency-response capability, upgrade emergency-preparedness equipment, and improve emergency-response operation skills.

At present, China's port industry lacks authoritative guidance and standards for emergency-response capability assessment. This study proposes targeted and operable elements of emergency-response capability construction and assessment in terms of the following four aspects: organizational system, legal basis, operation mechanism, and guarantee system. On that basis, a method for emergency-response capability assessment was developed. This method has practical significance for helping port businesses to understand the core points and key links of emergency-response capability, establish good emergency preparedness, and reduce accident impacts and losses.

\section{RESEARCH ON EMERGENCY- RESPONSE CAPABILITY ASSESSMENT}

The US and Japan have rich practical experience in emergency-response capability assessment ${ }^{[1]}$. Developed by the US government in 1997, the Capability Assessment for Readiness (CAR) has been implemented throughout the US and its territories. The CAR procedure includes 13 emergency-management functions that can be subdivided according to different attributes to fully cover all emergency-management functions for fine-grained emergency-response capabilities. The US government later established a more sophisticated emergency-response capability assessment system based on CAR. Japan, meanwhile, has established its own emergency-response capability assessments, focused on assessing the disasterprevention and crisis-management systems of public organizations. The results of such assessments can provide a reference for formulating policies and guidelines to improve regional disaster-prevention and crisismanagement capabilities. Australia has also developed ways to assess natural disaster management methods ${ }^{[2]}$, focused on areas such as disaster-preparedness programs, mitigation methods, disaster risk assessment, long- and short-term relief programs, and postdisaster recovery measures.

China has conducted a great deal of research on the assessment of urban emergency-response capability ${ }^{[3-6]}$. Such work has promoted further research and development related to emergency-response capability

\footnotetext{
aawangyukun@tk-aq.com biktguodong@163.com

c* Corresponding author: liwangyang@cooec.com.cn

dhuangyali@cooec.com.cn
} 
assessment. Yet, different emergency-response entities have different emergency-response requirements. In this regard, there is a need to consider the characteristics of port production to establish an assessment index system specific to the emergency-response capability of port businesses. Such work can help reflect the emergencyresponse preparedness of port businesses and guide the construction of emergency-response capability.

\section{MAIN FACTORS OF EMERGENCY- RESPONSE CAPABILITY ASSESSMENT FOR PORT BUSINESSES}

An emergency-response system is generally understood as a set of emergency-response plans, procedures, and resources, as well as the interrelationships among them, intended to reduce hazards. Emergency-response systems for port businesses are complex. In consideration of the specific characteristics of port-business emergency management, an emergency-response system should have a reasonable organizational structure, a solid legal basis, a rigorous operation mechanism, and sound guarantee system. Therefore, this study divided the emergencyresponse capability of port businesses into four parts: organizational system, legal basis, operation mechanism, and guarantee system. Each section consists of several elements, as shown in Figure 1.

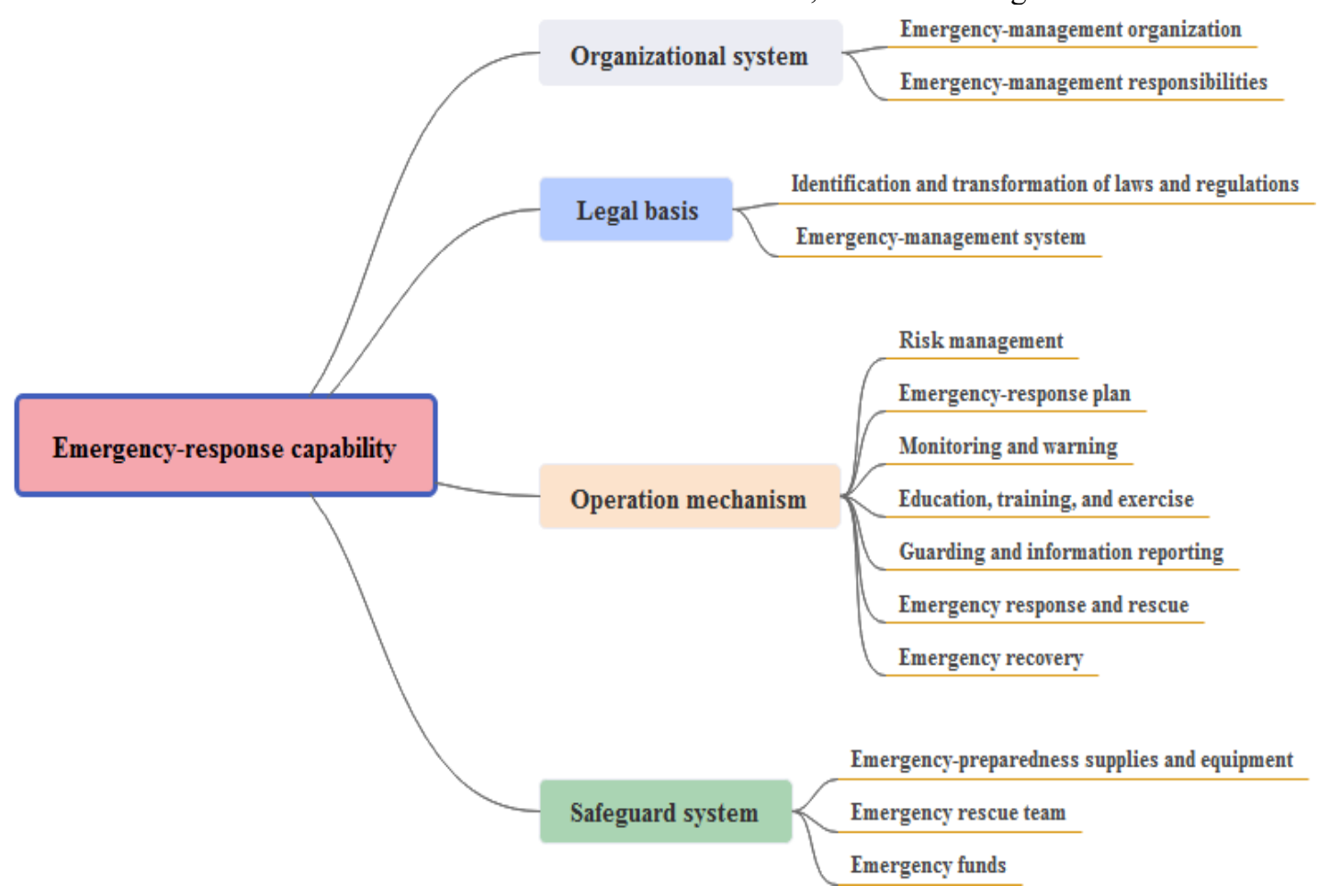

Figure 1. Emergency-response capability system framework

\subsection{Organizational system}

The organizational structure includes emergency-response organization and responsibilities. In a complete emergency-management organizational system, clear and reasonable relationships and a clear division of labor provide the institutional guarantees for port businesses to conduct emergency-management work. A reasonable organizational structure determines whether the emergency-management system can support the needs of the different levels and scopes of emergency management. The emergency-management organizational system includes the form of the organizational structure and the internal relations, functions, and operational processes of the organization. In this regard, port businesses need to establish and improve their organizational system of emergency management, refine emergency-management responsibilities, and ensure the implementation of the organizational system its related responsibilities.

\subsection{Legal basis}

The legal basis includes the identification and transformation of laws and regulations related to the emergency-management system. The emergencymanagement system is intended to guarantee the effective implementation of port businesses' emergencymanagement work and the standardization of emergencymanagement actions. Port businesses need to follow the requirements of existing laws, regulations, standards, norms, and guidelines in the construction of their emergency-response capabilities. They should also stay abreast of the latest safety and emergency managementrelated guidelines and render them into operable emergency-management work rules and operating procedures.

\subsection{Operation mechanism}

Operation mechanisms include risk management, emergency-response plans, monitoring, early warning 
systems, education, training and drills, guarding and information reporting, emergency response, rescue, and recovery. Emergency-operation mechanisms should give full consideration to the operational characteristics and functions of each emergency-management element to ensure that each element's functions are clear and that the elements are coordinated in an orderly, precise manner. In this way, efficient and scientific guidelines, procedures, and measures can be formed to effectively deal with unexpected incidents.

\subsection{Guarantee system}

The guarantee system includes emergency-preparedness supplies and equipment, rescue teams, and funds. The guarantee system refers to all kinds of resources needed for emergency-response processes. This system plays a very important role in emergency rescue processes and provides an important guarantee for successful responses to all manner of port accidents.

\section{Method for assessing the emergency- response capability of port businesses}

An index system for emergency-response capability assessment should cover all elements involved in the emergency-response capability of port businesses. Each factor index should be selected based on the characteristics of safety and emergency rescue processes, the size and level of the index system should be reasonable, and the dominant relationships between indicators should be fully considered. Important, representative indicators should be selected to simplify complexity for operability.

\subsection{Determination of assessment indicators}

Based on laws/regulations, standards/norms, and advanced emergency-management experience, this study determined the assessment indexes, content, methods, and rules of each aspect of emergency-response capability to construct an emergency-response capability assessment method for port businesses. Assessment can flexibly include discussion, data acquisition, on-site inspection, oral interviews, practical operations, and written testing. As shown in TABLE I, this study investigated riskidentification and assessment indicators.

TABLE I . Emergency-response capability assessment worksheet for port businesses (example)

\begin{tabular}{|c|c|c|}
\hline Assessment indicators & Assessment method & Assessment rules \\
\hline Risk identification & $\begin{array}{l}\text { Data collection: } \\
\text { 1. Risk identification and management } \\
\text { system. } \\
\text { 2. Record of risk identification. } \\
\text { Site inspection: } \\
\text { 1. Analyze the technological process and } \\
\text { judge whether the main risk points are } \\
\text { missing through on-site inspection. } \\
\text { Personnel inquiry: } \\
\text { 1. Question the staff on-site about their } \\
\text { participation in risk identification and } \\
\text { whether they know about the points of } \\
\text { risk, risk events, and their harmful } \\
\text { consequences (accident types), as well } \\
\text { as the risk factors of their positions. }\end{array}$ & $\begin{array}{l}\text { 1. If the risk identification method or procedure is not applicable or } \\
\text { inconsistent with the actual situation of the business, deduct } 2 \\
\text { points. } \\
\text { 2. The classification of risk points is obviously unreasonable, and } \\
\text { the main production process, equipment/facilities, working } \\
\text { environment, personnel behavior, and safety management of the } \\
\text { business are not fully covered, as well as operational activities with } \\
\text { risks implemented in the equipment and facilities, parts, places, and } \\
\text { regions. In that case, } 3 \text { points are deducted for each item/aspect } \\
\text { omitted. } \\
\text { 3. If risks are not identified and reasonably expressed for each risk } \\
\text { point one by one, } 2 \text { points are deducted for each item. } \\
\text { 4. Failure to conduct risk-factor analysis for each type of risk event } \\
\text { at each risk point will result in the deduction of } 2 \text { points each. } \\
\text { 5. Incomplete identification, obvious omission, or unreasonable risk } \\
\text { factors of major risk events will result in the deduction of } 1 \text { point } \\
\text { for each. } \\
6 \text {. People who do not participate in risk identification will lose } 2 \\
\text { points. } \\
\text { 7. Failure to identify hazard sources according to dynamic } \\
\text { management requirements will result in } 2 \text { points deducted. }\end{array}$ \\
\hline
\end{tabular}

\subsection{Determination of assessment indicators weights}

In this study, the weight coefficients of the assessment indexes were obtained using the Delphi method while integrating the experience and judgment of several emergency-management experts.

1) Delphi method

In the Delphi method, also known as the expert investigation method, a problem is sent to experts individually. Expert opinions are then collected, summarized, and sorted out. The method is anonymousthe experts do not discuss the problem with each other and only have contact with the investigators. After repeated consultation, induction, and modification, experts' views on the problem raised in the questionnaire are summarized into more or less consistent opinions, which are then used as the predicted results. This method is considered representative and reliable. Figure 2 shows the Delphi method process.

2) Determining index weights

A questionnaire was created for the assessment items to determine the index weights. Seven industry experts (see TABLE $\|$ for the distribution of experts) were invited to give opinions on the indicator weights. Each expert graded the importance of the indicators using a percentage system. The arithmetic average value of each indicator was divided by the total average value of all indicators, and its quotient was the weight coefficient of the indicator.

The weight coefficients of the indicators were 
determined through multiple rounds of questionnaire surveys. The first round was conducted in the form of an email or on-site questionnaire for the evaluation of the preliminarily identified indicators. The second round was also conducted via e-mail or on-site questionnaires and included feedback on the results of the previous round. The indicators were then reevaluated on that basis. This process was repeated until coordination among the experts reached the maximum degree. The coefficient of variation $(\mathrm{CV})^{[7]}$ was used to reflect fluctuations in the experts' assessments of the relative importance of an index and to reflect the coordination degree of the index. Taking into consideration the actual emergency-management work of port businesses, a standard coefficient of variation of $<15 \%$ was determined and confirmed after collective assessment by the research group. After five rounds of assessment, the assessment items and weight coefficients were determined, as shown in TABLE III.

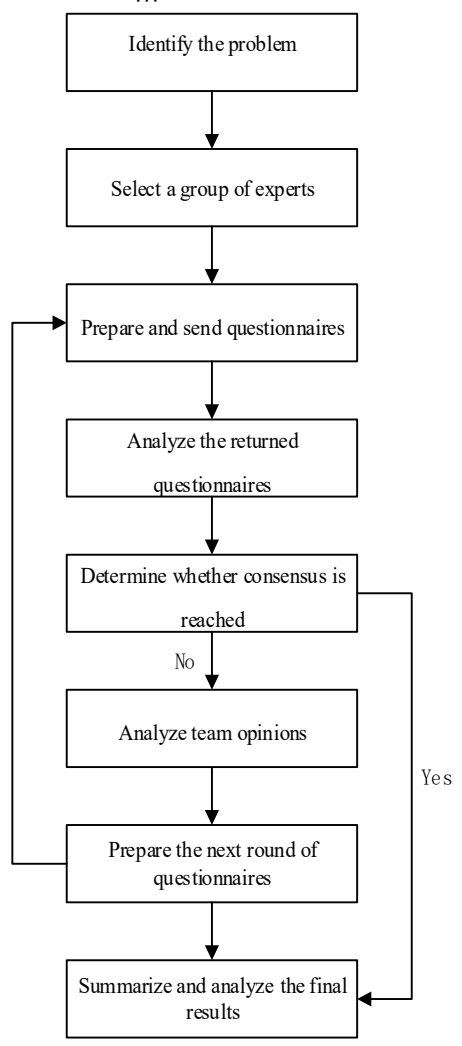

Figure 2. Diagram of Delphi process

The formula for calculating $\mathrm{CV}$ is as follows:

$\mathrm{CV}=\sigma / \mathrm{M}$

where $\sigma$ is the standard deviation of an index score, and $\mathrm{M}$ is the mean score of a certain index.

3) Scoring method

a) The full score of each assessment item is 100 points. The assessment requirements for each assessment item are executed as shown in TABLE I .

b) The total assessment score is 100 . This study used the following calculation:

$$
M=\sum_{1}^{n} \mathrm{KiMi}
$$

where $\mathrm{M}$ is the total score, $\mathrm{Ki}$ is the weight coefficient (the value is as specified in TABLE III), Mi is the score of each assessment item, and $n$ is the number of items to evaluate.
TABLE II . Distribution of the seven experts

\begin{tabular}{|c|c|c|c|}
\hline No. & Category & Entity & $\begin{array}{c}\text { Years } \\
\text { working } \\
\text { in the } \\
\text { field } \\
\end{array}$ \\
\hline 1 & $\begin{array}{c}\text { Administrativ } \\
\text { e department } \\
\text { of ports }\end{array}$ & $\begin{array}{c}\text { Transportation Department of } \\
\text { Province A }\end{array}$ & 23 \\
\hline 2 & $\begin{array}{c}\text { Port security } \\
\text { management } \\
\text { personnel }\end{array}$ & $\begin{array}{l}\text { Safety and Environmental } \\
\text { Department of Port B }\end{array}$ & 15 \\
\hline 3 & $\begin{array}{c}\text { Port security } \\
\text { management } \\
\text { personnel }\end{array}$ & $\begin{array}{l}\text { Safety and Environmental } \\
\text { Department of Port C }\end{array}$ & 18 \\
\hline 4 & $\begin{array}{c}\text { Personnel in } \\
\text { charge of } \\
\text { security of } \\
\text { port } \\
\text { businesses } \\
\end{array}$ & $\begin{array}{l}\text { Container Terminals } \\
\text { Corporation of Port D }\end{array}$ & 15 \\
\hline 5 & $\begin{array}{l}\text { Personnel in } \\
\text { charge of } \\
\text { security of } \\
\text { port } \\
\text { businesses } \\
\end{array}$ & $\begin{array}{l}\text { Bulk Grocery Terminal } \\
\text { Corporation of Port E }\end{array}$ & 12 \\
\hline 6 & $\begin{array}{l}\text { Personnel in } \\
\text { charge of } \\
\text { security of } \\
\text { port } \\
\text { businesses }\end{array}$ & $\begin{array}{l}\text { Petrochemical Terminal } \\
\text { Corporation of Port F }\end{array}$ & 11 \\
\hline 7 & $\begin{array}{c}\text { Third-party } \\
\text { security } \\
\text { services }\end{array}$ & Corporation $\mathrm{G}$ & 27 \\
\hline
\end{tabular}

TABLE III. Weight coefficients of emergency-response capability assessment index scoring

\begin{tabular}{c|c|c|c}
\hline No. & Assessment indicator & $\begin{array}{c}\text { Coefficient of } \\
\text { variation (\%) }\end{array}$ & $\begin{array}{c}\text { Weight } \\
\text { coefficient }\end{array}$ \\
\hline 1 & $\begin{array}{c}\text { Emergency-management } \\
\text { organization }\end{array}$ & 5.79 & 0.03 \\
\hline 2 & Emergency-management duty & 6.42 & 0.03 \\
\hline 3 & $\begin{array}{c}\text { Identification and } \\
\text { transformation of laws and } \\
\text { regulations }\end{array}$ & 9.17 & 0.02 \\
\hline 4 & $\begin{array}{c}\text { Emency-management } \\
\text { system }\end{array}$ & 8.25 & 0.03 \\
\hline 5 & Risk management & 9.46 & 0.12 \\
\hline 6 & Emergency-response plan & 7.87 & 0.13 \\
\hline 7 & Monitoring and early warning & 9.22 & 0.09 \\
\hline 8 & $\begin{array}{c}\text { Education, training, and } \\
\text { exercise }\end{array}$ & 10.07 & 0.08 \\
\hline 9 & $\begin{array}{c}\text { Guarding and information } \\
\text { reporting }\end{array}$ & 9.89 & 0.07 \\
\hline 10 & $\begin{array}{c}\text { Emergency-management and } \\
\text { rescue }\end{array}$ & 6.93 & 0.12 \\
\hline 11 & Emergency recovery & 9.34 & 0.03 \\
\hline 12 & $\begin{array}{c}\text { Emergency-preparedness } \\
\text { supplies and equipment }\end{array}$ & 9.71 & 0.11 \\
\hline 13 & Emergency rescue team & 8.35 & 0.11 \\
\hline 14 & Emergency funds & 6.94 & 0.03 \\
\hline
\end{tabular}

\section{Application of emergency-response capability assessment method}

In June 2020, five units at a certain port were randomly selected to conduct emergency-response capability assessment, using the proposed system. Scores were given following the assessment rules. The on-site scoring results were multiplied by the weight coefficients assigned to the importance of each index. These were added together to obtain the total score for a unit's emergency-response capability. The results were then sorted, as shown in TABLE IV.

The results indicated that the higher the score, the lower the number of accidents/incidents recorded by the business in the last five years. Moreover, businesses with 
higher scores had fewer safety-inspection problems. The company with the lowest score had had a fire accident in its office area as a result of a short circuit in May 2020. In that case, the absence of emergency-management measures at the accident scene was the main reason for the expansion of the accident. There was also insufficient fireextinguishing equipment at the scene. The two available fire extinguishers failed because they were expired. Also, after the fire broke out, company personnel did not immediately carry out rescue operations, leading to an escalation of the fire. This failure to properly respond to the accident exposed the shortcomings of the business' emergency-response capability. Aside from this particular business, the results for the five units indicated that the emergency-response capabilities of port businesses generally face many problems and deficiencies, as detailed below.

1) China's "One Plan, Three Systems" mechanism has not been sufficiently constructed and standardized. Existing emergency-response plans tend to be abstract and lacking in operability; some are ineffective and only developed for inspections. Drills and assessments are mere formalities, and plan revisions lag behind. In terms of legal construction, the measures that need to be formulated based on national emergency-management laws/regulations and standards/norms are imperfect and need further refinement. Regarding system construction, the relationship between port businesses and safetyrelated administrative departments needs improvement, and responsibilities related to emergency-management work need further clarification. In terms of mechanism construction, the connection between local businesses and the upper and lower system regime is still relatively weak.

2) Emergency-response and rescue capabilities need to be strengthened. Port businesses have an insufficient number of full- and part-time emergency rescue teams, and rescue training and emergency-response drills are insufficient. Moreover, rescue equipment is insufficient, coordination between port businesses and local emergency rescue teams is inadequate, and the responsibilities of relevant parties are unclear. There is also a mismatch between the types of emergency-preparedness supplies and actual operational requirements. Some port businesses rely on each other, but the synergistic mechanisms are unclear, and it is difficult to guarantee the provision of emergency supplies after an accident. Joint emergencyresponse measures are not specific enough and thus lack effectiveness. Emergency warning, information reporting, and emergency-response processes need to be further standardized. After an accident, the emergency-response mechanism should be further strengthened, in which the causes, development trends, and impact areas of accidents are evaluated to facilitate quick decision-making.

TABLE IV. Results of the emergency-response capability assessments

\begin{tabular}{c|c|c}
\hline No. & Entity Name & Score \\
\hline 1 & Port business A & 92.5 \\
\hline 2 & Port business B & 89.2 \\
\hline 3 & Port business C & 83.4 \\
\hline 4 & Port business D & 77.1 \\
\hline 5 & Port business E & 68.6 \\
\hline
\end{tabular}

\section{Conclusion}

This study constructed an emergency-response capability assessment index system. Based on existing laws, regulations, standards, referring to this study, port businesses should determine their emergency-response capabilities according to the characteristics of port accidents and the actual requirements of safe production. Then, they should establish a system to improve their level of emergency management and further strengthen their emergency-response capabilities. Finally, there is a need to improve the allocation of emergency-response resources for port accidents, promote the emergencyresponse capability of businesses, and ensure production safety.

\section{Acknowledgment}

This paper is supported and funded by programs with Fundamental Research Funds for the Central Public Welfare Research Institutes (Grant no. TKS190108, TKS 20200316, TKS 20200320) and Science and Technology Project of Qinghai Provincial Department of Transportation 2019-13.

\section{References}

1. Liang CG. Environmental emergency capability evaluation of dangerous goods terminal in Shanghai Port [D]. Shanghai: East China University of Science and Technology, 2010:10-11.

2. Zhang ST. Research on Evaluation of Emergency Management Capability in Petrochemical Enterprise [D]. Beijing: China University Of Petroleum,2015:4.

3. Wang SY. Constructions of emergency management capability to urban disasters[J]. Cities \& Disaster Reduction,2003(3):4-6.

4. Deng YF, Zheng SZ, Liu GZ. Study on city emergency capability assessment system[J]. Journal of Safety Science And Technology,2005,1(6):33-36.

5. Tie YB, Tang C. Establish the evaluation system of urban disaster emergency response capability[J]. Urban Problems,2005(6):76-79.

6. Yang Q, Tian YN, Song YH. Comprehensive capability evaluation system of the urban disaster emergency management based on process management $[\mathrm{J}]$. Chinese Public Administration,2007(3):103-106.

7. Ke HX, Shen H. Statistical analysis methods in investigation and research [M]. 2nd Edition. Beijing: Communication University of China Press, 2005:324. 